\title{
Milled basalt fibers as reinforcement for polyurea composite spray coatings with improved thermomechanical stability and mechanical performance*)
}

\author{
Mateusz Barczewski ${ }^{1), * *)}$, Kinga Biedrzycka ${ }^{1)}$, Olga Mysiukiewicz ${ }^{1)}$, Danuta Matykiewicz ${ }^{1)}$, \\ Jacek Andrzejewski ${ }^{1}$, , Arkadiusz Kloziński ${ }^{2)}$, Marek Szostak ${ }^{1)}$
}

DOI: dx.doi.org/10.14314/polimery.2020.3.3

\begin{abstract}
The novel polyurea-based (PUA) composites modified with milled basalt fibers (BMF), formed with spray coating technology were produced. The addition of 5-30 wt \% of BMF into commercial two-component PUA was used as a low-cost modification which allowed to significantly improve the mechanical performance, as well as thermomechanical and thermal stability of the final products. It was found that the incorporation of $30 \mathrm{wt} \%$ of BMF resulted in over $30 \%$ stiffness improvement and extension using temperature of the coating above $80{ }^{\circ} \mathrm{C}$. Moreover, an increase by $25^{\circ} \mathrm{C}$ in thermal stability evaluated by thermogravimetric analysis (TGA) was achieved, without significant changes in the rheological behavior of the compositions, resulting in the presence of structural defects. Finally, an evaluation of crosslink density was conducted in order to ascertain that the applied modification of the thermoset reactive fast-curing system allows to obtain fully cured products which may be used as a spray coating for hydrotechnical objects protection.
\end{abstract}

Keywords: polyurea, composite, spray coating, basalt fiber, thermomechanical properties.

\section{Mielone włókna bazaltowe jako wzmocnienie polimocznikowych kompozytowych powłok natryskowych o zwiększonej stabilności termomechanicznej i wytrzymałości mechanicznej}

\begin{abstract}
Streszczenie: Metodą powlekania natryskowego wytworzono nowe kompozyty na bazie polimocznika (PUA) modyfikowanego mielonymi włóknami bazaltowymi (BMF). Komercyjny dwuskładnikowy PUA modyfikowano niskokosztowo za pomocą dodatku 5-30\% mas. BMF, co pozwoliło na wyraźną poprawę właściwości mechanicznych, a także stabilności termomechanicznej i termicznej PUA. Stwierdzono, że wprowadzenie do polimocznika 30\% mas. BMF zwiększyło o ponad 30\% jego sztywność i umożliwiło rozszerzenie zakresu temperatury stosowania powłoki powyżej $80{ }^{\circ} \mathrm{C}$. Metodą analizy termograwimetrycznej (TGA) stwierdzono wzrost stabilności termicznej o $25^{\circ} \mathrm{C}$, bez istotnych zmian w reologicznym zachowaniu kompozycji, mogących prowadzić do tworzenia się wad strukturalnych w gotowych wyrobach. Na podstawie oceny gęstości usieciowania potwierdzono, że przeprowadzona modyfikacja termoutwardzalnego reaktywnego systemu szybkiego utwardzania pozwala na uzyskanie w pełni utwardzonych produktów, które można zastosować jako powłokę natryskową do ochrony obiektów hydrotechnicznych.
\end{abstract}

Słowa kluczowe: polimocznik, kompozyt, powłoka natryskowa, włókno bazaltowe, właściwości termomechaniczne.

The growing knowledge of the influence of exploitation and weathering conditions on the durability over the whole life cycle of steel and concrete construction elements requires the development of novel protective methods. One of the most extensively developed protection methods used for large scale civil engineering objects, especially those made of concrete, is the application of polyurea (PUA) and polyurethane (PUR) elastomeric spray coatings [1, 2]. Their benefi-

\footnotetext{
1) Poznan University of Technology, Institute of Materials Technology, Piotrowo 3, 61-138 Poznan, Poland.

2) Poznan University of Technology, Institute of Chemical Technology and Engineering, Berdychowo 4, 60-965 Poznan, Poland.

*) The article is the content of the poster presented during the VII Scientific Conference Polymer Materials "Pomerania-Plast 2019", June 5-7, 2019, Międzyzdroje, Poland.

**) Author for correspondence: mateusz.barczewski@put.poznan.pl
} 
cial set of properties includes good mechanical performance, high chemical resistance, hydrophobicity, and - most importantly - the fact that they can be easily applied on a large scale, at a wide temperature range and harsh environmental conditions, in the form high pressure spray coatings. Thanks to all those benefits polyurea has become the most intensively developed material for concrete and cement corrosion protection [3, 4]. Polyurea coatings are insusceptible to water exposition and have low permeability, and as such they make an ideal material for manufacturing moisture barrier coatings, which is the reason behind their wide application for hydrotechnical objects and hydraulic objects protection [5]. The second important range of application of polyurea spray coatings is as blast protection of ceramic and composite structures, especially long fiber reinforced thermoset structures, such as glass fiber reinforced epoxy composites [6]. In case of the application of two-component sprayed polyurea coatings on exterior concrete or masonry objects subjected to impact load or blast, the polyurea's large scale elongation during short term load enables the dissipation of significant amounts of energy, as well as save continuous membrane holding the crushed structure [7].

Even though polyurea is already characterized by a wide range of satisfying properties, it can be further improved in order to broaden the application possibilities of this polymer. The main approach is the modification of the properties of polyurea spray coating products with chemical methods, including the addition of different chain extenders and modifiers increasing polyurea's crosslink density and influencing structure $[8,9]$ as well as the selection of an accurate isocyanates [10]. However, the second approach of the two-component polyurethane or polyurea systems modification method achieved through incorporating inorganic fillers, offers new perspectives [11, 12] including extending the range of those materials as well as providing a low cost and easily introduced improvement of selected properties. The use of inorganic fillers, both particle- and fiber-shaped, characterized with high stiffness, hardness, as well as chemical and thermal stability usually results in beneficial changes in the final isocyanate-based thermoset composites properties $[13,14]$.

Fiber-shaped fillers are mostly applied in order to improve the mechanical properties of the composites. Nantasetphong et al. $[15,16]$ discuss the influence of the addition of milled glass fiber on the dynamic properties of polyurethane and polyurea composites. They found that the incorporation of short glass fiber (GF) into the polyurea matrix provides a distinct improvement in materials stiffness in a wide temperature range. However, not only short fibers may be used for manufacturing of polyurea-based protective coatings; the application polyurea-woven fiberglass composites used for developing shock-resistant steel plate reinforcement was discussed by Liao and his team [17]. Basalt fibers (BF) are currently a growing competition for glass fibers which are the most commonly used fiber-shaped filler used for both thermoset as well as thermoplastic polymeric materials [18-21]. BF are characterized by higher performance than the glass fiber with lower energy consumption necessary for their production and lack of necessity of any additives application during the manufacturing process $[18,22]$. Moreover, as it was presented in the studies of Greco et al. [23] adhesion between polymeric matrix is higher for basalt fibers in comparison to glass fibers. Hydrogen bonds present at surface of basalt fibers without sizing [24] allow to treat them as a reactive filler in case of addition to composition containing isocyanate. Moreover, not only mechanical properties may be improved by adding an inorganic filler. A different approach was presented by Fu et al. [25] who synthesized a hybrid filler based on halloysite nanotubes (HNT) modified with $\mathrm{Fe}_{2} \mathrm{O}_{3}$ and $\mathrm{AgNO}_{3}$ which allows to develop polyurea composites with improved magnetic and antibacterial properties.

The aim of this study is to evaluate the possibilities of the modification of the polyurea two-component spray coating system with micrometric milled basalt fibers in order to obtain high thermomechanical stability as well as improved mechanical and abrasive properties. Despite many studies focused on the application of short and long basalt fibers into various polymers, there is no evidence regarding this modification in case of polyurea spray coatings with short-curing time. The novel approach results from research into the improvement of polyurea coating mechanical performance without modifying preliminary prepared two-component composition. Mechanical properties studies were devised to analyze the composites structure, changes of rheological properties influencing the processing, as well as crosslink density of final products.

\section{EXPERIMENTAL PART}

\section{Materials}

Commercial diphenylmethane diisocyanate (MDI) prepolymer-based two-component aromatic polyurea for spray coating application Purex AM SL (Polychem Systems, Poland) was used as a polymeric matrix. The polyurea system was characterized with $30 \mathrm{~s}$ gel time, full curing time of $24 \mathrm{~h}$, mixing ratio of $1: 1$ and application temperature range of $65-85^{\circ} \mathrm{C}$. The material was specially prepared by the producer for the purpose of the experiment. Basalt milled fiber (BMF) MICF0021 purchased from Incotelogy (Germany) was used as a filler. The fiber-shaped filler without sizing was characterized with 8-13 $\mu$ m diameter, 5-150 $\mu \mathrm{m}$ length, 2.65-2.75 g/ $/ \mathrm{cm}^{3}$ density and moisture content, determined with TGA as mass loss at $130{ }^{\circ} \mathrm{C}, 1.23 \%$. According to the data provided by the producer BMF are characterized with the following chemical structure: $41-55 \% \mathrm{SiO}_{2}, 10-20 \% \mathrm{Al}_{2} \mathrm{O}_{3}, 7-18 \%$ $\mathrm{FeO} / \mathrm{Fe}_{2} \mathrm{O}_{3^{\prime}} 6-13 \% \mathrm{CaO}, 1-15 \% \mathrm{MgO}, 2-7.5 \% \mathrm{Na}_{2} \mathrm{O}, 0.5-3 \%$ $\mathrm{TiO}_{2}$. SEM image of BMF is presented in Fig. 1. 


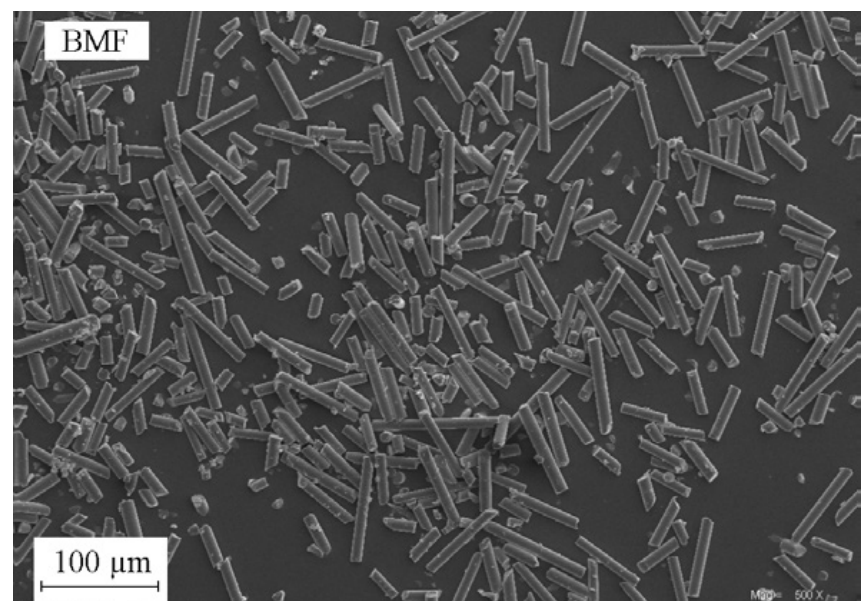

Fig. 1. SEM image of the milled basalt fibers

\section{Sample preparation}

The milled basalt fibers were dried using a Memmert ULE500 laboratory drier at $70{ }^{\circ} \mathrm{C}$ and $24 \mathrm{~h}$ before processing and mixing. Polyamine was preliminary mechanically mixed with 5, 10, 20 and 30\% of BMF by its weight in reference to polyamine by ProLab Disperlux laboratory mixer, with rotational speed of $1000 \mathrm{rpm}$ for $15 \mathrm{~min}$ under the subatmospheric pressure of $0.02 \mathrm{MPa}$. Dispersions were degassed additionally for 10 minutes without mechanical stirring and then placed in disposable two-component $1500 \mathrm{~cm}^{3}$ cartridges. Isocyanate was also applied to the cartridge after degassing for 10 minutes, in the same volume as the previously used polyamine and polyamine-BMF dispersion. The cartridge was conditioned at elevated temperature of $80{ }^{\circ} \mathrm{C}$ for 30 minutes before application. The spray coating process was done with Sulzer Mixpac ${ }^{\mathrm{TM}}$ spray gun equipped with $80 \mathrm{~mm}$ Quadro static mixer. Final mixing of the isocyanate with pure and filled with BMF polyamine compositions was realized continuously during the forming in static mixer. Coatings were formed in silicon $180 \times 120 \times 8 \mathrm{~mm}$ molds and on $1 \times 1 \mathrm{~m}$ teflon plate. Figure 2 shows a photography of the spray coating process.

\section{Methods of testing}

- The viscosity values of the polyamine premixes filled with various amounts of BMF were determined using a rotational rheometer Anton Paar MCR 301 operated with $25 \mathrm{~mm}$ parallel plates measuring system with the gap of $0.3 \mathrm{~mm}$. The measurements were taken in constant shear mode using either $1 \mathrm{~s}^{-1}, 10 \mathrm{~s}^{-1}$ or $100 \mathrm{~s}^{-1}$ shear rate at $30^{\circ} \mathrm{C}$. The presented dynamic viscosity results are mean values taken from $300 \mathrm{~s}$ experiment.

- The samples' fractures were examined and digitally captured using a scanning electron microscope Evo 40 (Carl Zeiss Microscopy $\mathrm{GmbH}$ ). The electron accelerating voltage of $12 \mathrm{kV}$ was applied. Prior to the tests, all specimens were broken after cooling in liquid nitrogen below the PUA glass transition temperature and sputtered with a layer of gold. The magnifications of 200× and 1000× were used.

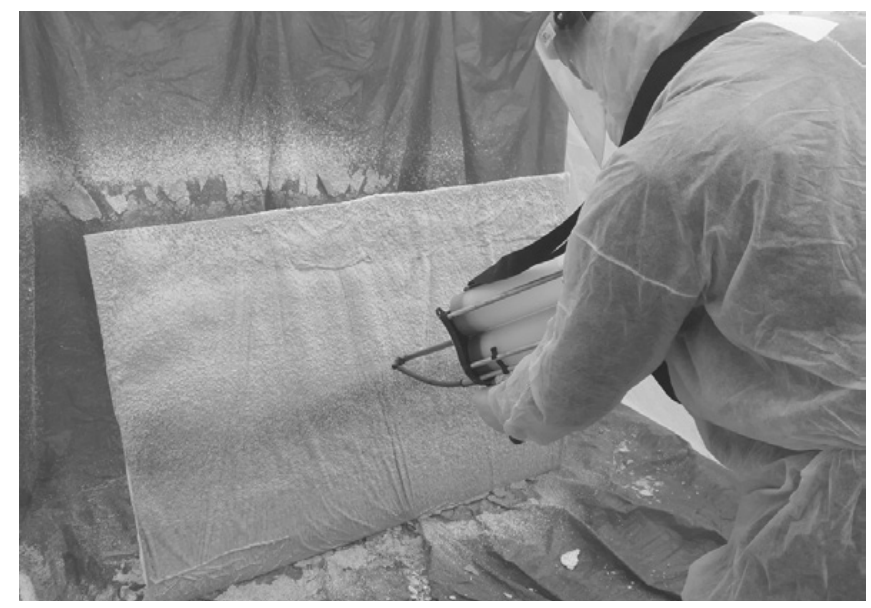

Fig. 2. Preparation of polyurea spray coatings

- Swelling and crosslink density of the polyurea and polyurea composites was determined by the equilibrium swelling method [26]. The initial mass of the samples was measured using a Radwag XA52/2X balance with the resolution of $0.01 \mathrm{mg} .3 \mathrm{~g}$ material samples, 3 of each kind, were then immersed in $100 \mathrm{~cm}^{3}$ of tetrahydrofuran (THF) for 72 hours in order to dissolve the non-cured phase of the polymer. According to the literature $72 \mathrm{~h}$ immersion time is sufficient to obtain equilibrium point [27]. During this process, the samples were kept at room temperature, out of sunlight. After that, the samples were removed from the solvent, weighted again and dried in a Binder FD53 laboratory drier at $40^{\circ} \mathrm{C}$ for one week to evaporate the remaining THF. The final mass of the specimens was measured using the Radwag XA52/2X balance. The swelling ratio was calculated according to following Equation (1) [28]:

$$
Q=\frac{m_{s}-m_{0}}{m_{0}} \cdot 100 \%
$$

where: $Q$-swelling degree, $m_{s}$ - mass of the swollen sample after $72 \mathrm{~h}$ immersion in solvent, $m_{0}$-initial sample mass.

The crosslink density $v_{e}$ was determined according to Flory-Rehner Equation (2) [26]:

$$
v_{e}=\frac{-\left[\ln \left(1-v_{r}\right)+v_{r}+\chi v_{r}^{2}\right]}{v_{l}\left(v_{r}^{1 / 3}-\frac{v_{r}}{2}\right)}
$$

where: $v_{r}$ - gel volume in swollen sample, $v_{l}$ - solvent molar volume $\left(79.76 \mathrm{~cm}^{3} / \mathrm{mol}\right), \chi$ - polymer-solvent interaction parameter.

The equilibrium volume fraction in the swollen state $v_{r}$ with allowance of filler content was calculated using the Equation (3) [29]:

$$
v_{r}=\frac{\left(W_{d}-W_{f}\right) / \varrho}{\left[\left(W_{d}-W_{f}\right) / \varrho\right]+\left[\left(W_{s}-W_{d}\right) / \varrho_{s}\right]}
$$

where: $W_{d}$ - is the mass of the sample after immersion in the solvent and drying, $W_{f}$ - is the mass of the filler in 
the sample, $W_{s}$ - is the mass of the swollen sample, $\mathrm{Q}-$ is the density of the polymer, $\mathrm{Q}_{\mathrm{s}}-$ is the density of the solvent, $Q_{\mathrm{s}}=0.889 \mathrm{~cm}^{3} / \mathrm{g}$ for THF.

The Flory-Huggins interaction parameter $\chi$ for polyurea and tetrahydrofuran (0.48) was calculated according to the Equation (4) [29]:

$$
\chi=\chi_{\beta}+\frac{v_{1}}{R T}\left(\delta_{s}-\delta_{p}\right)^{2}
$$

where: $\chi_{\beta}-$ is the entropic contribution, $\chi_{\beta}=0.34$ [30], $V_{1}$ - molar volume of solvent $\left(81.11 \mathrm{~cm}^{3} / \mathrm{mol}\right.$ for THF), $R-$ gas constant, $T$ - the absolute temperature $(293 \mathrm{~K}), \delta_{s}$ and $\delta_{p}$ - are the Hildebrand solubility parameters of the solvent and the polymer $\left[\delta_{s}=9.1\left(\mathrm{cal} / \mathrm{cm}^{3}\right)^{1 / 2}, \delta_{p}=11.2\left(\mathrm{cal} / \mathrm{cm}^{3}\right)^{1 / 2}\right]$ [31].

- The Fourier transform infrared spectroscopy (FT-IR) measurements were conducted with a Jasco FT/IR-4600 spectrometer, at room temperature $\left(23^{\circ} \mathrm{C}\right)$ in the attenuated total reflectance mode (ATR FT-IR). A total of 64 scans at a resolution of $4 \mathrm{~cm}^{-1}$ was used in all cases to record the spectra. All spectra were subjected to $\mathrm{H}_{2} \mathrm{O}$ and $\mathrm{CO}_{2}$ correction.

- The mechanical properties such as Young's modulus $(E)$, tensile strength $(R m)$, tensile strength measured at $100 \%$ strain $R m_{\varepsilon=100 \%}$, elongation at break $(\varepsilon)$ of polyurea and polyurea-based composites were investigated by static tensile test according to ISO 527 standard with a Zwick/Roel Z020 UNT at room temperature and crosshead speed of $100 \mathrm{~mm} / \mathrm{min}$. The integrated area under stress-strain curve, corresponding to the energy of the samples break was used to determine toughness [32].

- Hardness was evaluated using the Sauter HBD 100-0 Shore D durometer according to ISO 868 standard.

- Abrasion resistance experiments were realized with an APGi wear apparatus according to the Schopper-Schlobach method described in ISO 4649 standard.

- Vicat softening temperature (VST) investigations were prepared with the use of the CEAST HV3 apparatus, in an oil bath in accordance with ISO 306 standard, respectively. VST was determined in A50 measurement configuration, i.e. load $10 \mathrm{~N}$ and heating rate $50{ }^{\circ} \mathrm{C} / \mathrm{h}$.

- The dynamic thermomechanical analysis (DMTA) was performed using Anton Paar MCR 301 rheometer equipped with a torsion DMA measuring tool. The analyses were conducted at a constant frequency of $1 \mathrm{~Hz}$ and a strain of $0.01 \%$. All samples were cooled down to $-100{ }^{\circ} \mathrm{C}$ and heated up to $160{ }^{\circ} \mathrm{C}$ with the temperature ramp of $2{ }^{\circ} \mathrm{C} / \mathrm{min}$.

- The thermal properties were determined by thermogravimetric analysis (TGA) with the temperature set between $30{ }^{\circ} \mathrm{C}$ and $900{ }^{\circ} \mathrm{C}$ at a heating rate of $10^{\circ} \mathrm{C} / \mathrm{min}$ under nitrogen atmosphere using a TG 209 F1 Netzsch apparatus. $5 \pm 0.1 \mathrm{mg}$ samples were placed in ceramic pans. The initial decomposition temperature $T_{i}$ was determined as the temperature at which the mass loss was $5 \%$. The residual mass $(\Delta W \%)$ was defined at about $900{ }^{\circ} \mathrm{C}$. Additionally, thermal decomposition was measured at $10 \%$ and $50 \%$ mass losses (W10\% and $W 50 \%$ ).

\section{RESULTS AND DISCUSSION}

\section{Rheological properties}

Figure 3 presents the results of the rheological measurements realized for pure polyamine and premixes of polyamine with various amounts of BMF as a viscosity values determined at three different shear rates. Both unmodified and modified with BMF polyamines reveal shear thinning behavior: the higher the shear rate, the lower the viscosity. It can be seen that the incorporation of up to $20 \mathrm{wt} \%$ of BMF into polyamine did not significantly affect its rheological properties. The addition of $30 \mathrm{wt} \%$ of the filler results in over $200 \%$ value of viscosity measured at all considered shear rates. This phenomenon is related to the incorporation of the inorganic fibrous filler with high aspect ratio [33]. It can be suspected that the addition of the higher amounts of the filler into polyamine may cause problems with proper processing behavior, including stable dosing, mixing with unmodified isocyanate in static mixer and hindered degassing providing to increased amount of entrapped air in form of pores.

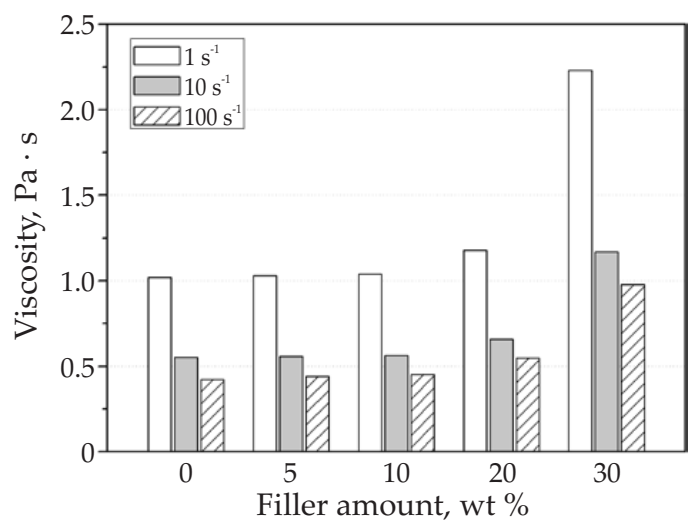

Fig. 3. Viscosity of polyamine premixes containing BMF at different shear rates

\section{Structure of spray-coated PUA composites}

In Fig. 4 SEM images of PUA and PUA-BMF composites realized with two different magnifications are presented. It can be seen that the incorporation of the BMF into the PUA matrix caused significant changes in its structure. The pore size and distribution were strongly influenced by the addition of the fiber-shaped filler into polyamine. It should be underlined that all samples including unmodified PUA were subjected to the same mixing and degassing procedure prior to processing. The pure PUA spray-coated sample showed high amounts of large pores in its structure that were absent in composite samples, the addition of even $5 \mathrm{wt} \%$ of BMF resulted in a decreased ability to form regular-shaped structural defects. It can be assumed that the small sized pores observed in the composite samples were caused by their 

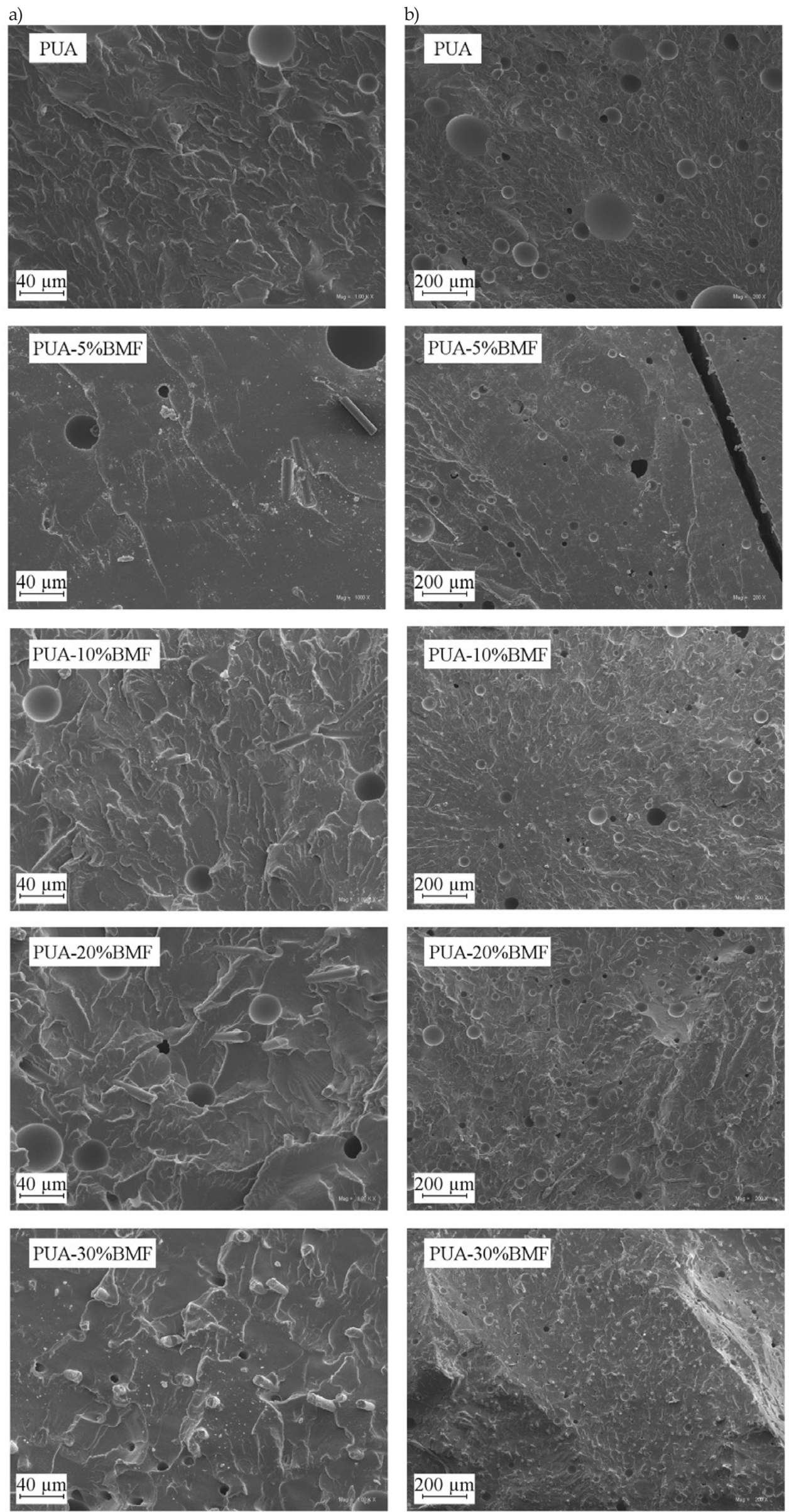

Fig. 4. SEM images of PUA and PUA-BMF composites, mag.: a) 200×, b) 1000× 
a)

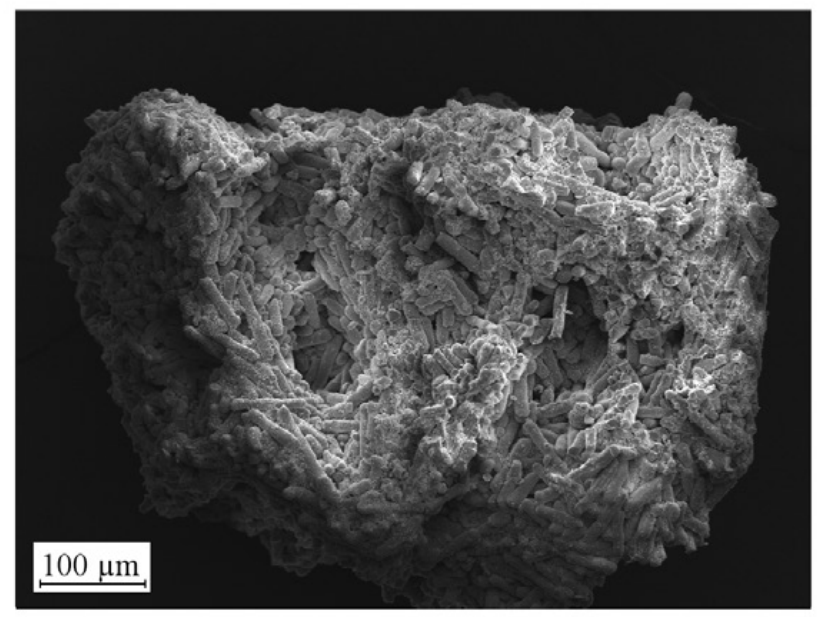

b)



Fig. 5. SEM images of PUA-30\%BMF composite after annealing at $850{ }^{\circ} \mathrm{C}$, mag.: a) $500 \times$, b) $1000 \times$

creation during mixing of polyamine premix, while macroscopic pores observed only in the PUA sample result from the coating processing. Lower viscosity of the unfilled composition resulted in an increased ability to entrap air during the spraying process. Moreover, thanks to the structural analysis it can be stated that the increase in the PUA-30\%BMF compositions' viscosity did not cause the creation of structural defects in the final composite in the form of the high number of the voids. Only in case of composites containing 20 and 30 wt \% of BMF regular distribution of the fibers was observed. Despite the high number of the pull-out holes observed in the brittle fractured surface of the composites, residual and dominant number of the fibers are well saturated with the polyurea matrix.

Figure 5 shows an additional SEM image of the composite residue after annealing PUA-30\%BMF at $850{ }^{\circ} \mathrm{C}$ for 6 hours at air. The structural analysis was performed in order to exclude the effect of basalt fibers mechanical degradation during mixing and spray coating processes. It can be seen that all fibers have similar length and there is no evidence of crushed basalt fibers, which confirms the applicability of basalt fibers as a filler for spray coating purposes resistant to both preprocessing by high speed mixing as well as spray coating with high shear rates.

\section{FT-IR analysis}

Figure 6 shows FT-IR spectra measured in the ATR mode of solid PUA and PUA-BMF composite samples. For all considered materials typical for aromatic polyurea absorption bands were denoted. The characteristic absorption bands from polyeteroamines were denoted at $926 \mathrm{~cm}^{-1}\left(\mathrm{CH}-\mathrm{O}-\mathrm{CH}_{2}\right.$ symmetric stretching) and $1096 \mathrm{~cm}^{-1}$ (CH-O- $\mathrm{CH}_{2}$ asymmetric stretching) as well as amines: $1013 \mathrm{~cm}^{-1}$ (C-N stretching) [34]. Band with origin from isocyanate was observed at $1452 \mathrm{~cm}^{-1}\left(\mathrm{sp}^{3} \mathrm{CH}_{2}\right), 1372 \mathrm{~cm}^{-1}$
( $\mathrm{N}=\mathrm{C}=\mathrm{O}$ symmetric stretching). Moreover, bands characteristic for polyurea were measured at: $1230 \mathrm{~cm}^{-1}$ and $1309 \mathrm{~cm}^{-1}$ (CO stretching corresponding to carboxylic acid), $1372 \mathrm{~cm}^{-1}$ (CH bonds in plane alkenes), $1409 \mathrm{~cm}^{-1}$ (CF stretching of alkyl halides), $1596 \mathrm{~cm}^{-1}$ (CO-N-H amide II from urea), $1508 \mathrm{~cm}^{-1}$ (nitro compounds $\mathrm{NO}_{2}$, asymmetric), $1643-1667 \mathrm{~cm}^{-1}$ and $1688 \mathrm{~cm}^{-1}$ (NCO groups of isocyanurate ring), $2867 \mathrm{~cm}^{-1}$ and $2968 \mathrm{~cm}^{-1}$ (CH stretching from aldehyde), $3306 \mathrm{~cm}^{-1}$ (NH amides stretching) [34, 35].

It should be mentioned that there were no significant differences between the spectrum of pure PUA and filled samples, in form of additional absorption peaks or peak shifts. In order to confirm the full curing reaction of PUA and composites the presence of non-reacted isocyanate groups (NCO) in solid samples were analyzed. None of the measured samples exhibited absorption peak at $2770 \mathrm{~cm}^{-1}$ at FT-IR spectra, which corresponds to the mentioned MDI functional groups and confirms the lack of the inhibiting effect of BMF on polyurea spray coating [36].

\section{Swelling behavior and crosslink evaluation}

The results of immersion in solvent experiments are presented in Table 1. The incorporation of BMF into the polyurea matrix resulted in a decrease in the swelling degree of the composites in comparison to the unmodified sample. This phenomenon may be related to the improved rigidity of the material resulting from the reinforcing effect of the fibers as well as high interfacial interactions between isocyanate-based thermoset polymer and inorganic filler [28, 37]. Those interactions limited the penetration of the solvent into the samples, as a result of restricted mobility of polymeric chains. The addition of $5 \mathrm{wt} \%$ of BMF resulted in almost $50 \%$ decrease in the swelling degree, while for the composite with the highest content of the fibrous inorganic filler this parameter was only $0.5 \%$. Both gel volume fraction in swollen phase as well as crosslink density of the 


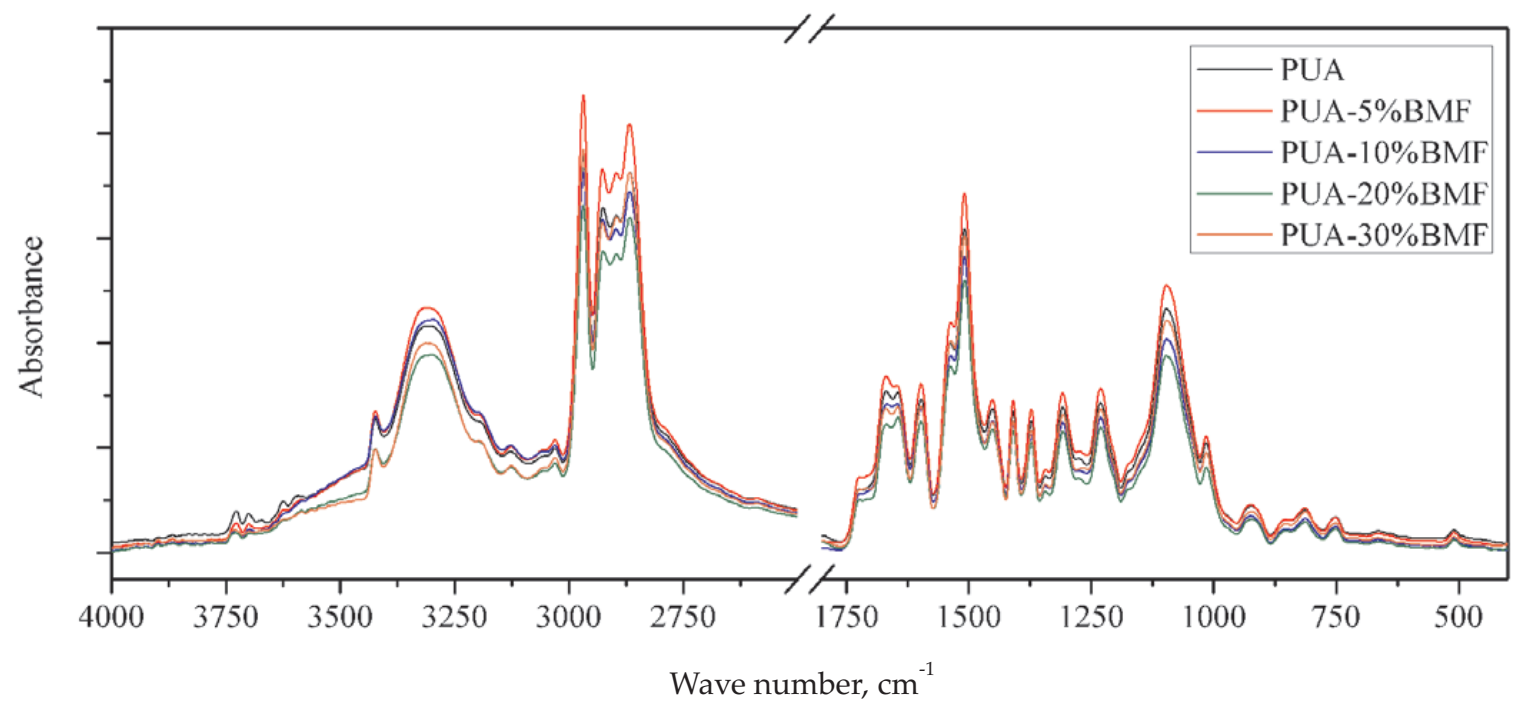

Fig. 6. FT-IR spectra of solid PUA and PUA-BMF samples

composite samples increased as a function of the BMF content. The higher amount of the inorganic filler, the higher values of $v_{r}$ and $v_{e}$. The developed materials were produced by partial removal of polyamine by the inorganic filler which resulted in changes in polyurea reactivity. The increase in the number of isocyanate groups in filled compositions probably reacted with hydroxyl groups occurring on chemically untreated basalt fiber [24], which led to the creation of rigid urethane groups between isocyanate and BMF instead of urea bonds with polyetheramines and polyamines.

\section{Mechanical properties}

The mechanical properties of PUA and PUA-BMF composites including the results of static tensile test (tensile strength, elasticity modulus and elongation at break) and hardness evaluation are presented in Fig. 7.

The mean value of Young's modulus for unmodified polyurea sample was approx. $195 \mathrm{MPa}$, while the addition of the increasing amount of the milled basalt fibers resulted in a constant increase in this mechanical parameter from $220 \mathrm{MPa}$ (5 wt \% BMF) to $249 \mathrm{MPa}$ (20 wt \% BMF). A further increase in the filler content caused a notable increase in the stiffness of the composites (349 MPa for $30 \mathrm{wt} \% \mathrm{BMF}$ ); this phenomenon may be interpreted as exceeding of the amount of the short fibers which allowed to obtain an effective reinforcing effect. For tensile strength evaluated at $100 \%$ strain and at break of the sample, different tendencies caused by the addition of the BMF were observed. Tensile strength measured at $100 \%$ strain changed gradually with the increasing content of the filler, and the incorporation of the highest amount of the BMF (30 wt \%) allowed to obtain a $100 \%$ increase in $R m_{\varepsilon=100 \%}$ value in reference to the unmodified sample. The course of tensile strength changes measured at break induced by the addition of inorganic fibrous filler vary from values determined at a lower strain. The addition of $5 \mathrm{wt} \%$ of BMF caused an increase from 7.06 MPa noted for PUA to $11.9 \mathrm{MPa}$. A further increase in the filler amount (10 wt \% and more) led to a considerable improvement in tensile strength (up to $16.7 \mathrm{MPa}$ ), which was almost independent of BMF content in the composite. It can be stated that the enhancement of mechanical properties is a simultaneous effect of inorganic fibers incorporation as well as an improvement of crosslink density of composite materials. Elongation at break was at a comparable level for all the measured samples and exceeding $300 \%$, which suggests that the addition of BMF did not cause brittleness of PUA-BMF composites and potential limitations to their application. Moreover, BMF incorporation into two component polyurea spray system caused an advantageous effect of Shore D hardness increase, from approximately

T a b l e 1. Swelling properties and crosslink densities of PUA and PUA-BMF composites

\begin{tabular}{c|c|c|c}
\hline \multirow{2}{*}{ Material } & Swelling degree, $Q$ & Gel volume fraction in swollen phase, $v_{r}$ & Crosslink density, $v_{e}$ \\
\cline { 2 - 4 } & $\%$ & - & $\left(\mathrm{mol} / \mathrm{cm}^{3}\right) \cdot 10^{-4}$ \\
\hline PUA & $8.48 \pm 0.55$ & $0.092 \pm 0.009$ & $0.142 \pm 0.034$ \\
PUA-5\%BMF & $4.52 \pm 1.02$ & $0.129 \pm 0.007$ & $0.303 \pm 0.041$ \\
PUA-10\%BMF & $2.55 \pm 1.05$ & $0.142 \pm 0.017$ & $0.371 \pm 0.012$ \\
PUA-20\%BMF & $2.61 \pm 1.19$ & $0.138 \pm 0.009$ & $0.332 \pm 0.058$ \\
PUA-30\%BMF & $0.47 \pm 0.25$ & $0.175 \pm 0.004$ & $0.524 \pm 0.030$ \\
\hline
\end{tabular}


a)

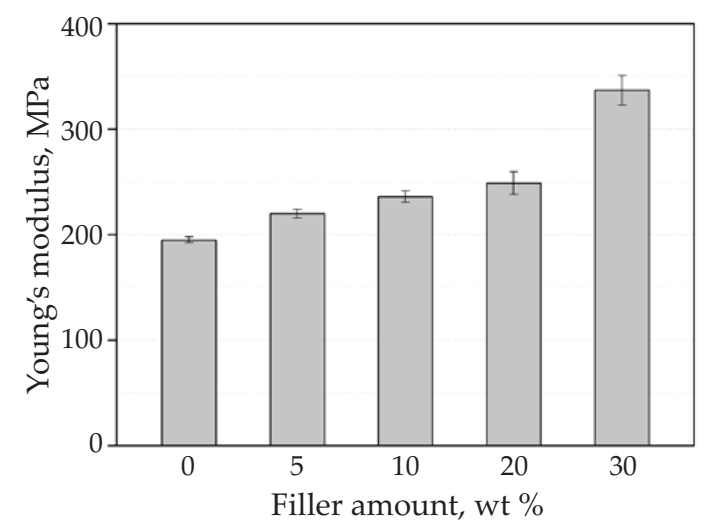

c)

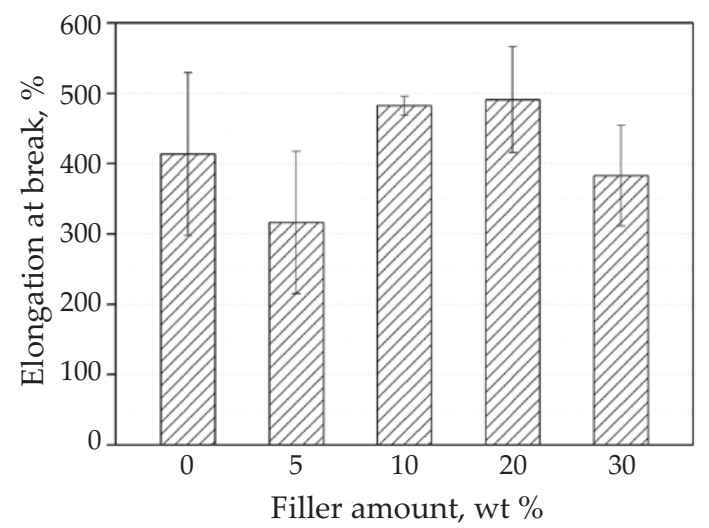

b)

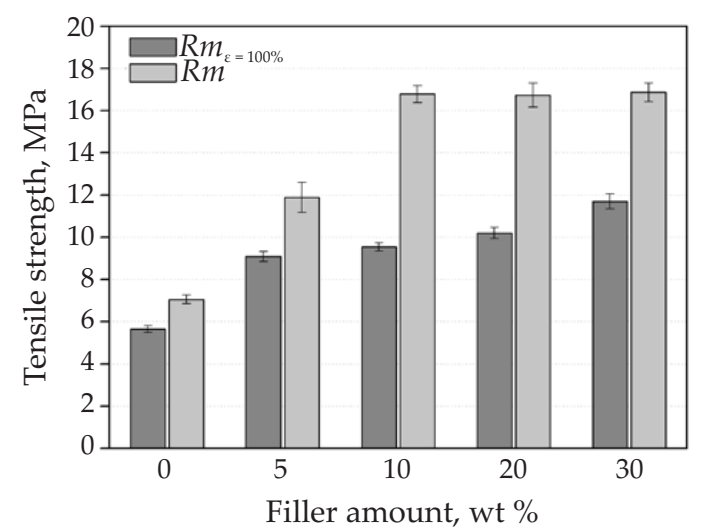

d)

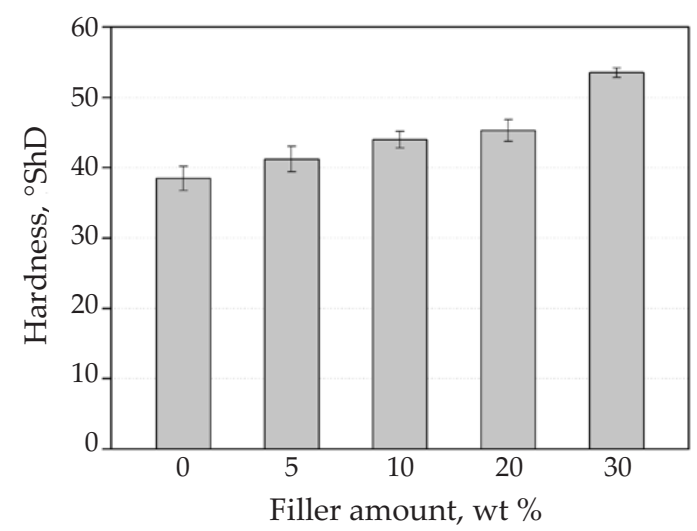

Fig. 7. Mechanical properties of PUA and PUA-BMF composites: a) Young's modulus, b) tensile strength, c) elongation at break, d) hardness

$38^{\circ}$ ShD for unmodified PUA to $54^{\circ}$ ShD in case of $30 \mathrm{wt} \%$ of the filler incorporation. A gradual increase in hardness and relatively low standard deviations in mechanical properties resulted confirm good dispersion of the filler in polymeric matrix as it was proved in SEM analysis (Fig. 4). The results of PUA and PUA-BMF composites toughness determined as an area under the strain-stress curve are presented in Fig. 8. The highest toughness was denoted for the composite sample with 10 wt \% of BMF which may have resulted from the lack of overrigidity caused by the presence of insufficient amount of BMF in composite structure and high elasticity resulting from changes in crosslink density.

Elastomeric composites containing micrometric welldispersed fillers such as silica particles [38] usually showed improved abrasion resistance. In Fig. 9 the results of abrasion resistance test as well as measurements of the density are presented collectively.

Incorporating micrometric inorganic fibers, with low ability to create agglomerates allowed a decrease in abrasion resistance from $0.061 \mathrm{~cm}^{3}$ for the unmodified PUA to $0.041 \mathrm{~cm}^{3}$ value measured for $30 \mathrm{wt} \%$ content of the filler. The application of at least $10 \mathrm{wt} \%$ of the BMF allowed to obtain increased abrasion resistance. Further incorporation of the filler did not cause significant reduction of abrasion resistance measured as volume loss. The significant improvement in abrasion resistance resulted not only from the presence of rigid particles in composite materials subjected to the test, but also good adhesion between polyurea matrix and milled basalt fibers [39] and improvement of crosslink density of composites in comparison to unmodified PUA. The density of the materials increased as a function of the inorganic filler addition. The density of the basalt fibers is $2.78 \mathrm{~g} / \mathrm{cm}^{3}$, therefore the observed effect is reasonable. Lack of strong variations from the gradual increase in the density results from uniformly dispersed fibers in polyurea matrix as well as reduced number of pores, as was observed in Fig. 4.

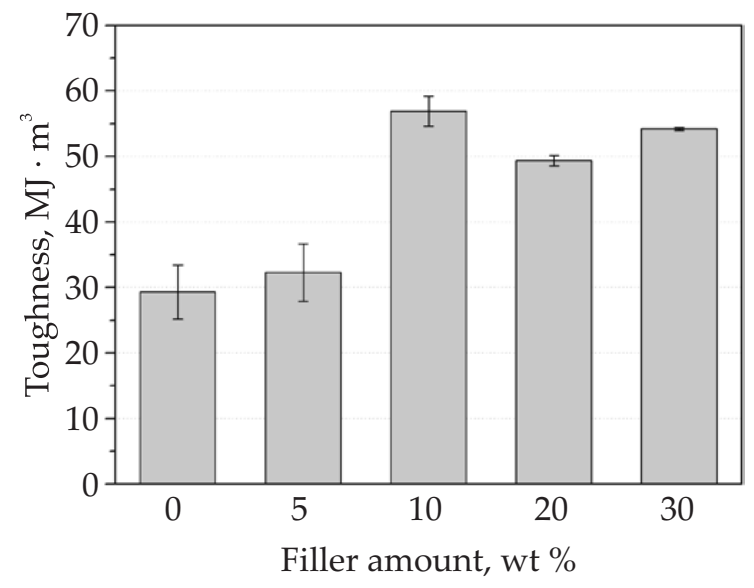

Fig. 8. Toughness of PUA-BMF composites 


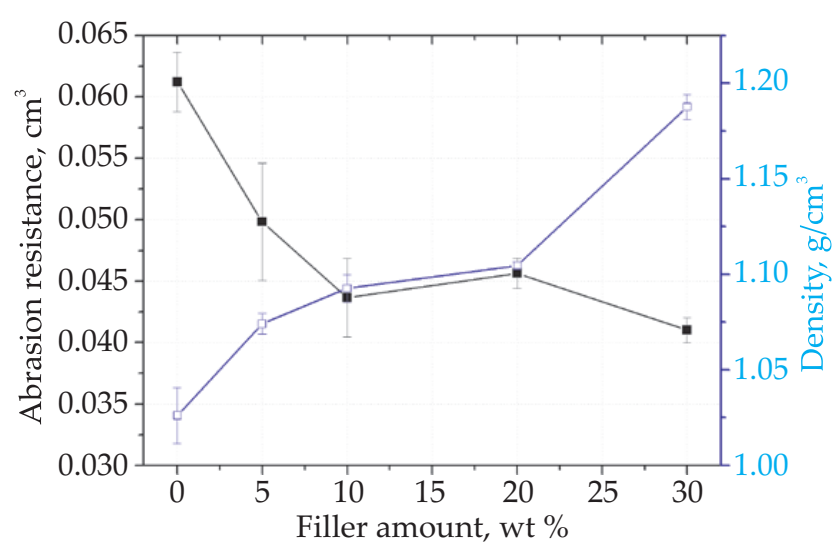

Fig. 9. Abrasive resistance and density of PUA and PUA-BMF composites

\section{Thermomechanical behavior}

In Fig. 10 the mean VST values of PUA and PUA composites as a function of filler content are presented.

Incorporation of increasing inorganic fibrous-filler amount into thermoset polymeric matrix resulted in a gradual improvement of the thermomechanical stability measured as static indentation of the needle in nonisothermal conditions. The difference between reference PUA samples and materials containing the highest amount of the filler was $27 \%$, which corresponded a to $23{ }^{\circ} \mathrm{C}$ increase in VST. Each amount of the filler used in the study caused changes in VST, however only composites containing $20 \mathrm{wt} \%$ and more of the BMF displayed VST higher than $80^{\circ} \mathrm{C}$, and may be treated as materials which may be used for elevated temperature applications. According to mechanical tests results, the increase in the VST may be rather related to the increase in composites hardness than to the catalytic behavior of BMF on PUA matrix during curing process and modification of its crosslink density.

Figure 11 shows DMTA analysis results of PUA and PUA-BMF composites filled with various amounts of BMF as a storage modulus $\left(G^{\prime}\right)$ and damping factor $(\tan \delta)$

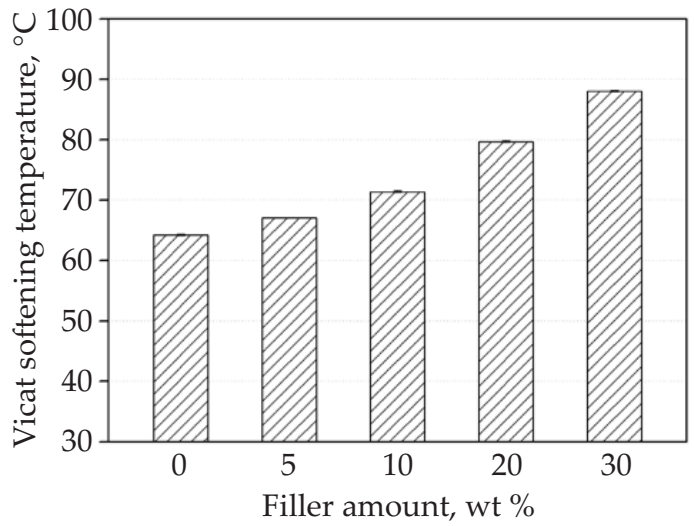

Fig. 10. Vicat softening temperature of PUA-BMF composites

vs. temperature $(T)$. The incorporation of $30 \mathrm{wt} \%$ of BMF caused a significant improvement in samples stiffness across the whole temperature range. The $G^{\prime}$ values of $30 \mathrm{wt} \%$ filled composites were significantly higher than those measured for the other tested materials, which is in a good agreement with the discussed results of elasticity modulus and VST. At tan $\delta$ vs. T curve two peaks are visible, $T g_{\mathrm{S}}$ (from -40 to $-20{ }^{\circ} \mathrm{C}$ ) related to soft segment glass transition and $\mathrm{Tg}_{\mathrm{H}}\left(140\right.$ to $\left.170{ }^{\circ} \mathrm{C}\right)$ referred to the presence of hard polyurea segments [40,41]. Detailed information about both relaxations as well as $G^{\prime}$ values measured at selected temperature values of $20^{\circ} \mathrm{C}$ and $80{ }^{\circ} \mathrm{C}$ are collectively presented in Table 2 .

The addition of inorganic fibrous filler caused a shift in the damping factor curve peak to higher temperature values at $T g_{\mathrm{S}}$ and $T g_{\mathrm{H}}$. Moreover, lowered values of $\tan \delta$ peaks as well as wider course of $T g_{\mathrm{H}}$ may be attributed to hindered movement of hard segments, which reduced phase separation [40, 42]. Polyurea used as a polymeric matrix was characterized with a dominant amount of hard segments in relation to soft segments. With increasing amount of the BMF values of maximum of tan $\delta$ peaks at both relaxations decreased, which suggests that the structure of spray coated composites was reinforced and

b)

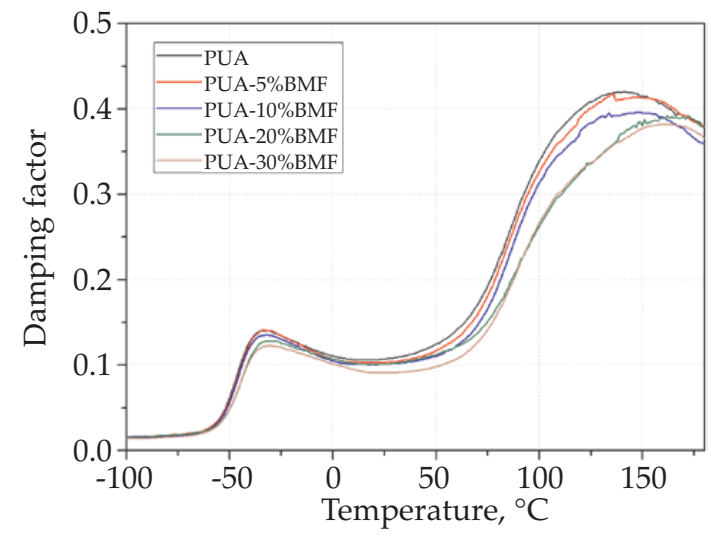

Fig. 11. DMA analysis of PUA-BMF composites: a) storage modulus, b) damping factor 
T a b l e 2. DMTA parameters of PUA and PUA-BMF composites

\begin{tabular}{|c|c|c|c|c|}
\hline \multirow{2}{*}{ Material } & $\operatorname{Tg}_{S} ; \tan \delta_{\text {peak }}$ & $\operatorname{Tg}_{\mathrm{H}} ; \tan \delta_{\text {peak }}$ & $G_{20{ }^{\circ} \mathrm{C}}^{\prime}$ & $G_{80{ }^{\circ} \mathrm{C}}^{\prime}$ \\
\hline & \multicolumn{2}{|c|}{${ }^{\circ} \mathrm{C}$; - } & \multicolumn{2}{|c|}{$\mathrm{Pa}$} \\
\hline PUA & $\begin{array}{l}-35.3 \\
0.141\end{array}$ & $\begin{array}{c}141 ; \\
0.419\end{array}$ & $1.37 \cdot 10^{8}$ & $4.18 \cdot 10^{7}$ \\
\hline PUA-5\%BMF & $\begin{array}{l}-34.3 \\
0.141\end{array}$ & $\begin{array}{c}145 \\
0.414\end{array}$ & $1.68 \cdot 10^{8}$ & $4.93 \cdot 10^{7}$ \\
\hline PUA-10\%BMF & $\begin{array}{c}-32 ; \\
0.136\end{array}$ & $\begin{array}{c}148 ; \\
0.395\end{array}$ & $1.86 \cdot 10^{8}$ & $6.09 \cdot 10^{7}$ \\
\hline PUA-20\%BMF & $\begin{array}{l}-29.9 \\
0.128\end{array}$ & $\begin{array}{c}165 \\
0.391\end{array}$ & $1.86 \cdot 10^{8}$ & $7.12 \cdot 10^{7}$ \\
\hline PUA-30\%BMF & $\begin{array}{l}-30.7 \\
0.123\end{array}$ & $\begin{array}{c}163 ; \\
0.382\end{array}$ & $8.15 \cdot 10^{8}$ & $3.09 \cdot 10^{8}$ \\
\hline
\end{tabular}

damping properties were reduced [43]. This phenomenon is in a good agreement with swelling experiments and increased crosslink density of the composites caused by addition of inorganic filler.

\section{Thermal stability}

Thermogravimetric analysis was conducted to examine the influence of the addition of basalt fiber on the polyurea matrix thermal stability. The results in form of sample mass loss and its derivative vs. temperature are presented in Fig. 12.

a)

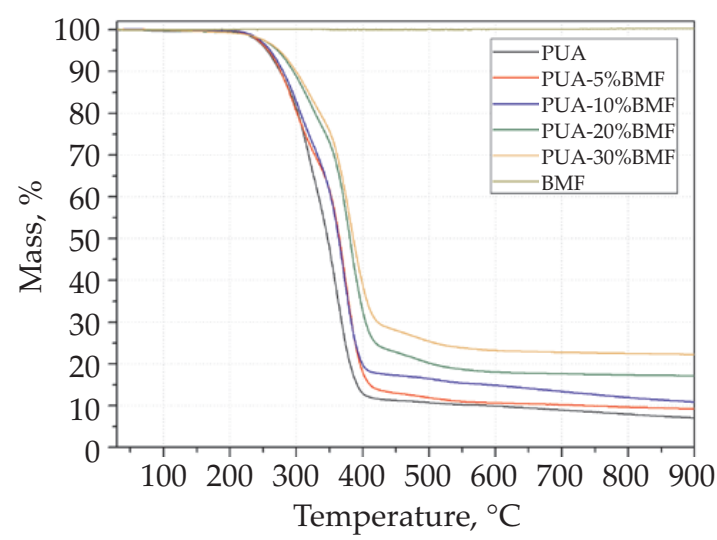

b)

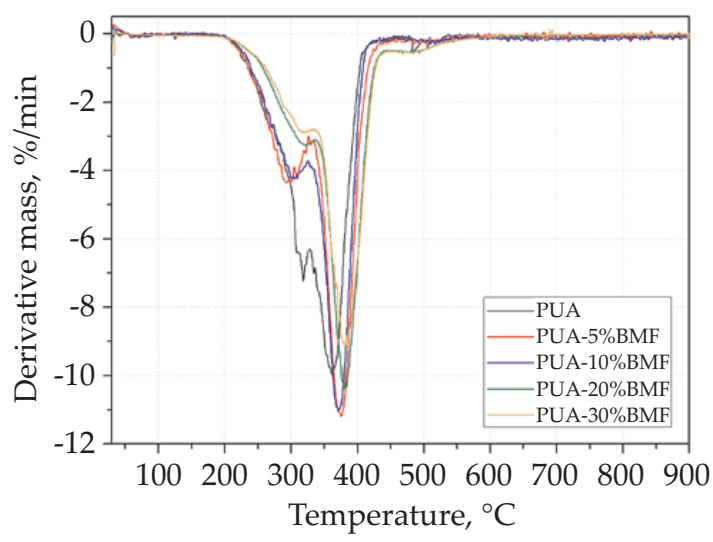

Fig. 12. a) TG, b) DTG curves of PUA-BMF composites
Specific information about thermal properties evaluated by TGA is collectively presented in Table 3 . The high thermal stability of basalt fibers influenced the shift of the material decomposition temperature towards higher values. In particular, for samples with 20 and 30 wt \% BMF, a significant increase in $W 5 \%$ and $W 10 \%$ values was observed (by approximately $20^{\circ} \mathrm{C}$ ). In the DTG curves two peaks were observed for all the investigated samples. The first peak was located in range $290-320^{\circ} \mathrm{C}$ and the second peak was visible in range $360-380^{\circ} \mathrm{C}$. All samples showed two-step of degradation. The first stage corresponded to the degradation of polyurea hard segment in view of low thermal stability of the urea group. The second step came from the soft segment decomposition process [44]. The hard segments degradation usually depends on the isocyanate type [44]. It should be stressed that the addition of BMF reduced the degradation rate of the composites. This is due to the replacement of a part of polyurea through the highly thermally stable basalt fiber. According to the literature at the end of the decomposition process the char residue is formed and all volatile species are released [44]. Due to the fact that the polyurea materials are sensitive to light and atmospheric degradation, the improvement of their thermal properties is important for application reasons.

\section{CONCLUSIONS}

Polyurea composites filled with milled basalt fibers were manufactured through the spray coating process. The addition of milled basalt fibers into commercial polyurea spray-coating systems may be a low-cost, easy to prepare modification which allows to obtain significant improvement of their mechanical performance as well as thermomechanical properties. The observed effects resulted from simultaneously occurring reinforcing effects caused by the presence of rigid basalt fibers and the modification of the polyurea structure. The crosslink density evaluated by the equilibrium swelling test confirmed its almost 4 times improvement for the composites with $30 \mathrm{wt} \%$ content of the filler. Moreover, the addition of even $30 \mathrm{wt} \%$ of the BMF resulted in a relatively low increase in the composition's viscosity which did not create 
$\mathrm{T}$ a b 1 e 3. Selected values of mass loss, residual mass and information about DTG peaks obtained by TGA

\begin{tabular}{|c|c|c|c|c|c|c|}
\hline \multirow{2}{*}{ Material } & $W 5 \%$ & $W 10 \%$ & $W 50 \%$ & Residual mass & $1^{\text {st }}$ DTGA peak & $2^{\text {nd }}$ DTGA peak \\
\hline & \multicolumn{3}{|c|}{${ }^{\circ} \mathrm{C}$} & $\%$ & \multicolumn{2}{|c|}{${ }^{\circ} \mathrm{C} ; \% / \mathrm{min}$} \\
\hline PUA & 256.1 & 275.7 & 347.1 & 7.1 & $\begin{array}{c}319.2 \\
-7.19\end{array}$ & $\begin{array}{c}362.3 \\
-9.95\end{array}$ \\
\hline PUA-5\%BMF & 257.7 & 276.3 & 364.7 & 9.26 & $\begin{array}{r}291.0 \\
-4.43\end{array}$ & $\begin{array}{r}375.8 \\
-11.18\end{array}$ \\
\hline PUA-10\%BMF & 261.0 & 280.1 & 363.7 & 10.92 & $\begin{array}{r}303.6 \\
-4.25\end{array}$ & $\begin{array}{l}373.3 ; \\
-10.95\end{array}$ \\
\hline PUA-20\%BMF & 272.0 & 295.8 & 380.8 & 17.18 & $\begin{array}{l}321.2 \\
-3.27\end{array}$ & $\begin{array}{l}380.5 ; \\
-10.38\end{array}$ \\
\hline PUA-30\%BMF & 274.3 & 299.7 & 385.8 & 22.29 & $\begin{array}{r}319.1 ; \\
-2.90\end{array}$ & $\begin{array}{c}382.7 \\
-9.12\end{array}$ \\
\hline
\end{tabular}

limitations in high pressure spray applications and the creation of porous structure of final coating.

\section{ACKNOWLEDGMENTS}

This study was financed under project "Quick-setting hybrid composites for restoration of pipelines, including ground-based and vacuum ones", no. POIR.04.01.02-00-0097/16. The authors are grateful to Sulzer Mixpac AG for supplying the Sulzer Mixcoat ${ }^{T M}$ spray gun.

\section{REFERENCES}

[1] Guan S.W.: Coatings World 2003, pp. 49-58.

[2] Huang W.B., Xiang J.Y., Lv P. et al.: Advanced Materials Research 2011, 374-377, 1325.

http://dx.doi.org/10.4028/www.scientific.net/ AMR.374-377.1325

[3] https://www.pcimag.com/articles/84126-polyureaspray-coatings-the-technology-and-latest-developments (availability date 12.06.2019)

[4] Maj M., Ubysz A., Tamrazyan A.: MATEC Web of Conferences 2018, 251, 02026.

http://dx.doi.org/10.1051/matecconf/201825102026

[5] Wang X., Luo S., Liu G. et al.: Water Science and Engineering 2014, 7, 106. http://dx.doi.org/10.3882/j.issn.1674-2370.2014.01.01

[6] Iqbal N., Tripathi M., Parthasarathy S. et al.: RSC Advances 2016, 6, 109706. http://dx.doi.org/10.1039/C6RA23866A

[7] Malvar L.J., Crawford J.E., Morrill K.B.: Journal of Composites for Construction 2007, 11, 601.

h t t p://dx.doi.org/10.1061/(A SCE)10900268(2007)11:6(601)

[8] Iqbal N., Tripathi M., Parthasarathy S. et al.: Progress in Organic Coatings 2018, 123, 201. http://dx.doi.org/10.1016/J.PORGCOAT.2018.07.005

[9] Ryszkowska J.: Polimery 2012, 57, 777. http://dx.doi.org/10.14314/polimery.2012.777

[10] Sami S., Yildirim E., Yurtsever M. et al.: Polymer 2014, $55,4563$.

http://dx.doi.org/10.1016/j.polymer.2014.07.028
[11] Casalini R., Bogoslovov R., Qadri S.B. et al.: Polymer 2012, 53, 1282.

http://dx.doi.org/10.1016/j.polymer.2012.01.034

[12] Qiao J., Wu G.: Journal of Materials Science 2011, 46, 3935.

http://dx.doi.org/10.1007/s10853-011-5318-x

[13] Mizera K., Auguscik M., Woronka D. et al.: Polimery 2016, 61, 307.

http://dx.doi.org/10.14314/polimery.2016.307

[14] Ryszkowska J., Zieleniewska M., Bryskiewicz A. et al.: Polimery 2017, 62, 11.

http://dx.doi.org/10.14314/polimery.2017.011

[15] Nantasetphong W., Amirkhizi A.V., Jia Z. et al.: Mechanics of Materials 2016, 98, 111.

http://dx.doi.org/10.1016/j.mechmat.2016.04.006

[16] Nantasetphong W., Jia Z., Amirkhizi A.V.et al.: Mechanics of Materials 2016, 98, 142.

http://dx.doi.org/10.1016/j.mechmat.2016.04.005

[17] Liao Y., Shi S., Liu Z. et al.: International Journal of Protective Structures 2018, 9, 248.

http://dx.doi.org/10.1177/2041419618755159

[18] Fiore V., Scalici T., Di Bella G. et al.: Composites Part B: Engineering 2015, 74, 74.

http://dx.doi.org/10.1016/j.compositesb.2014.12.034

[19] Kuciel S., Kufel A.: Polimery 2018, 63, 387. http://dx.doi.org/10.14314/polimery.2018.5.8

[20] Matykiewicz D., Barczewski M., Pucała H.: Revista Romana de Materiale/Romanian Journal of Materials 2018, 48, 108.

[21] Zhou S., Wang J., Wang S. et al.: Materials Chemistry and Physics 2018, 217, 315.

http://dx.doi.org/10.1016/j.matchemphys.2018.06.080

[22] Sim J., Park C., Moon D.Y.: Composites Part B: Engineering 2005, 36, 504.

http://dx.doi.org/10.1016/j.compositesb.2005.02.002

[23] Greco A., Maffezzoli A., Casciaro G. et al.: Composites Part B: Engineering 2014, 67, 233.

http://dx.doi.org/10.1016/j.compositesb.2014.07.020

[24] Deak T., Czigany T., Tamas P. et al.: Express Polymer Letters 2010, 4, 590.

http://dx.doi.org/10.3144/expresspolymlett.2010.74 
[25] Fu H., Liao L., Li X. et al.: International Journal of Polymeric Materials and Polymeric Biomaterials 2016, 65, 863. http://dx.doi.org/10.1080/00914037.2016.1171220

[26] Flory P.J., Rehner J.: The Journal of Chemical Physics 1943, 11, 512. http://dx.doi.org/10.1063/1.1723791

[27] Jutrzenka Trzebiatowska P., Santamaria Echart A., Calvo Correas T. et al.: Progress in Organic Coatings 2018, 115, 41. http://dx.doi.org/10.1016/j.porgcoat.2017.11.008

[28] Colom X., Marín-Genescà M., Mujal R. et al.: Journal of Composite Materials 2018, 52, 3099. http://dx.doi.org/10.1177/0021998318761554

[29] Marzocca A.J.: European Polymer Journal 2007, 43, 2682. http://dx.doi.org/10.1016/J.EURPOLYMJ.2007.02.034

[30] Sheehan C.J., Bisio A.L.: Rubber Chemistry and Technology 1966, 39, 149. http://dx.doi.org/10.5254/1.3544827

[31] Brandrup J., Immergur E.H., Grulke E.A.: "Polymer Handbook", John Wiley \& Sons, Inc., New York 1999.

[32] Han J.H., Zhang H., Chen M.J. et al.: Composites Science and Technology 2014, 103, 63. http://dx.doi.org/10.1016/j.compscitech.2014.08.015

[33] Shenoy A.V.: "Rheology of filled polymer systems", Springer Netherlands, Dordrecht 1999. http://dx.doi.org/10.1007/978-94-015-9213-0

[34] Sánchez-Ferrer A., Rogez D., Martinoty P.: Macromolecular Chemistry and Physics 2010, 211, 1712. http://dx.doi.org/10.1002/macp.201000117

[35] Arunkumar T., Ramachandran S.: International Journal of Ambient Energy 2016, 38, 781. http://dx.doi.org/10.1080/01430750.2016.1222966

[36] Husić S., Javni I., Petrović Z.S.: Composites Science and Technology 2005, 65, 19. http://dx.doi.org/10.1016/j.compscitech.2004.05.020

[37] Mizera K., Chrząszcz M., Ryszkowska J.: Polymer Composites 2018, 39, 2019. http://dx.doi.org/10.1002/pc.24162

[38] Malaki M., Hashemzadeh Y., Fadaei Tehrani A.: Progress in Organic Coatings 2018, 125, 507. http://dx.doi.org/10.1016/j.porgcoat.2018.07.034

[39] Włoch M., Kosiorek P., Błażek K. et al.: Elastomery 2017, 21, 75.

[40] Zhou Q., Cao L., Li Q. et al.: Journal of Applied Polymer Science 2012, 125, 3695. http://dx.doi.org/10.1002/app.36674

[41] Garrett J.T., Xu R., Cho J. et al.: Polymer 2003, 44, 2711. http://dx.doi.org/10.1016/S0032-3861(03)00165-4

[42] Samson N., Mechin F., Pascault J.P.: Journal of Applied Polymer Science 1998, 70, 2331.

h t t p://dx.doi.org / 10.1002 / (S I C I) 1097 4628(19981219)70:12<2331::AID-APP4>3.0.CO;2-N

[43] Qin C.L., Cai W.M., Cai J. et al.: Materials Chemistry and Physics 2004, 85, 402. http://dx.doi.org/10.1016/j.matchemphys.2004.01.019

[44] Awad W.H., Wilkie C.A.: Polymer 2010, 51, 2277. http://dx.doi.org/10.1016/j.polymer.2010.03.033

Received 19 VI 2019. 